\title{
Chemical Composition and Bioactive Potential of Dehydrated Peels of Benincasa hispida, Luffa acutangula, and Sechium edule
}

\section{Shyamala Bellur Nagarajaiah \& Jamuna Prakash}

To cite this article: Shyamala Bellur Nagarajaiah \& Jamuna Prakash (2015) Chemical Composition and Bioactive Potential of Dehydrated Peels of Benincasa hispida, Luffa acutangula, and Sechium edule, Journal of Herbs, Spices \& Medicinal Plants, 21:2, 193-202, DOI: 10.1080/10496475.2014.940437

To link to this article: https://doi.org/10.1080/10496475.2014.940437

曲 Published online: 20 Aug 2014.

Submit your article to this journal ๘

III Article views: 322

View Crossmark data \ulcorner

Citing articles: 8 View citing articles $\sqsubset \nearrow$ 


\title{
Chemical Composition and Bioactive Potential of Dehydrated Peels of Benincasa bispida, Luffa acutangula, and Sechium edule
}

\author{
SHYAMALA BELLUR NAGARAJAIAH and JAMUNA PRAKASH \\ Department of Food Science and Nutrition, University of Mysore, Mysore, India
}

\begin{abstract}
Debydrated peels from ash gourd (Benincasa hispida), ridge gourd (Luffa acutangula), and cho-chow marrow (Sechium edule) were analyzed for chemical composition and bioactive potential. The range of constituents per $100 \mathrm{~g}$ dry peels were protein, 3 to $15 \mathrm{~g}$; insoluble fiber, 45 to $58 \mathrm{~g}$; ether extractives, 2.3 to $3.3 \mathrm{~g}$; iron, 5.1 to $17.4 \mathrm{mg}$; calcium, 307 to $704 \mathrm{mg}$; tannins, 580 to $848 \mathrm{mg}$; carotenoids, 1, 712 to 35,663 $\mathrm{gg}$; and ascorbic acid, 37 to $51 \mathrm{mg}$. Polyphenols, total antioxidant activity, free radical scavenging activity (FRSA), and reducing power of peel were highest in aqueous extracts. FRSA of cho-chow marrow peel was the highest (87.32\%) followed by ridge gourd (85.4\%) and ash gourd (63.31\%) peels that correlated well with bioactive components. Methanol and aqueous extracts of the peel exhibited bile acid binding (61\%-98\%) and $\alpha$-amylase inbibitory activity.
\end{abstract}

KEYWORDS Nutritional composition, antioxidant activity, bile acid binding, $\alpha$-amylase inbibition

\section{INTRODUCTION}

Processing of vegetables results in large amounts of by-products that can be used for various purposes in food, pharmaceutical, and cosmetic industries. Functional foods represent an important and rapidly growing part of the overall food market, and the exploitation of by-products of vegetable processing as a source of functional compounds is a promising field. To utilize

Received January 30, 2014.

Address correspondence to Jamuna Prakash, Department of Food Science and Nutrition, University of Mysore, Mysore, 570006 India. E-mail: jampr55@hotmail.com 
a byproduct as a food source, it should both be present at high content and value (18). The most common antioxidant components present in vegetables include ascorbic acid, carotenoids, and flavonoids. In this study, the chemical composition and bio-active potential of peels from three commonly used vegetables, namely, ash gourd, cho-chow marrow (also known as "cayote") and ridge gourd, were analyzed. Traditionally, the use of the peels of all these vegetables in Indian dietaries for preparation of dishes is limited.

\section{METHODS}

\section{Materials}

Three cucurbitaceous vegetables - ash gourd (Benincasa bispida, ridge gourd (Luffa acutangula), and cho-chow marrow (Sechium edule)-were purchased from a local market in one lot and processed. Peels were separated from edible portions, washed with distilled water, dried in oven at $50^{\circ} \pm 1^{\circ} \mathrm{C}$, powdered using a lab grinder, and stored in air-tight jars maintained at $4^{\circ} \mathrm{C}$ until use. The yield of peel from fresh vegetable and as dry powder was recorded. Chemicals used for the study LL-Ascorbic acid, $\beta$-carotene, and 2,2-Diphenyl-1-picrylhydrazyl (DPPH)\} were from Sigma Chemical Company (Sigma-Aldrich, USA), and all others were from E-Merck, Mumbai, or Qualigens Fine Chemicals, Mumbai, India. Double glass-distilled water was used for all analyses. Analyses were run in triplicates and averaged.

\section{Analysis}

\section{DETERMINATION OF CHEMICAL COMPOSITION}

Dehydrated peel samples were analyzed for proximate composition (2). Moisture estimation was carried out by vacuum oven (926.12, 41.1.02) method. Protein was determined by Kjeldahl nitrogen distillation (960.52, 12.1.07), and multiplying the nitrogen value with a 6.25. Soxhlet apparatus was used for total ether extractives using petroleum ether (948.22, 40.1.05). Ash was analyzed by direct analysis (942.05,4.1.10). Dietary fiber consisting of both insoluble and soluble fiber was estimated by enzymatic gravimetry (4). Iron and phosphorus were determined colorimetrically $(22,25)$. Calcium was precipitated as oxalate, dissolved in $\mathrm{H}_{2} \mathrm{SO}_{4}$ and titrated against potassium permanganate solution (19). Estimation of ascorbic acid was by 2, 6-dichlorophenol indophenol visual titration method (2). Powdered samples were extracted in acetone and transferred to petroleum ether phase for carotenoids estimation. Total carotene was read colorimetrically using petroleum ether for baseline correction. $\beta$-carotene was separated by column chromatography and read colorimetrically (23). Tannins were estimated by 
the colorimetric method by measuring the blue color formed by the reduction of phosphotungstomolybdic acid by tannin-like compounds in alkaline solution (1). Oxalates were extracted in hydrochloric acid, precipitated as calcium oxalate from the deproteinized extract and estimated by subsequent titration with potassium permanganate $(5,6)$. Phytic acid was extracted and determined as per the supernatant difference method (26).

\section{DETERMINATION OF BIOACTIVE POTENTIAL}

For estimation of polyphenols, flavonoids, and antioxidant activity, samples were extracted with ethanol and methanol and in aqueous medium; $1 \mathrm{~g}$ of sample was suspended in $100 \mathrm{~mL}$ solvent, allowed to extract for $3 \mathrm{~h}$ with agitation, centrifuged at 3,000 rpm, and filtered. All analyses were carried out in fresh extracts. Samples were analyzed for total polyphenol content as tannic acid equivalents (TAE) $100 \mathrm{~g}^{-1}$ of sample as per the Folin-Ciocalteu method (14). The total flavonoid content was determined using the Dowd method (3). Total antioxidant activity was determined by the phosphomolybdenum method (21). Free radical scavenging activity was analyzed using DPPH assay (16). Reducing power was measured by the formation of Perl's Prussian blue at $700 \mathrm{~nm}$ (20). Three methods as mentioned above were used for analysis of antioxidant activities and final values represent average of triplicate determinations. Alpha-amylase inhibition and bile acids binding ability of samples were determined as described earlier $(6,10)$. For both alpha-amylase inhibition and bile acid binding ability, the samples were run in triplicate and averaged.

\section{STATISTICAL ANALYSIS}

Correlation between the antioxidant components and the antioxidant activity of the peel (correlation coefficient, R) was determined using SPSS 10.0 for windows $(p<0.05)$. Nutritional data were subjected to analysis of variance, and the means were compared by Tukey's test.

\section{RESULTS}

\section{Chemical Composition of Vegetable Peels}

The peel yield as dry powder varied between $2.47 \%$ and $10.61 \%$. Bulk density varied between 55.57 and 66.66 g.100 mL $\mathrm{mL}^{-1}$ (Table 1). The moisture percentage of fresh peel was $90.1 \%$ to $94.1 \%$, whereas that of dry power was $6.08 \%$ to $8.21 \%$. Both ridge gourd and cho-chow marrow peel had protein content in a similar range of $14.10 \%$ and $15.15 \%$, respectively, whereas the ash gourd was low in protein (3.83\%). Ether extractives were higher in 
TABLE 1 Physical Characteristics and Chemical Composition of Dehydrated Vegetable Peels (per 100 g Fresh Weight)

\begin{tabular}{|c|c|c|c|}
\hline Parameters & Ash gourd & Ridge gourd & Cho-chow marrow \\
\hline Yield as (g) & $\begin{array}{l}40.28 \\
(5.83)\end{array}$ & $\begin{array}{l}29.91 \\
(2.47)\end{array}$ & $\begin{array}{l}11.11 \\
(10.61)\end{array}$ \\
\hline Bulk density (g) & $59.5 \pm 0.07$ & $55.57 \pm 1.45$ & $66.66 \pm 0.00$ \\
\hline Water absorption capacity (mL) & $680.0 \pm 0.00$ & $940.5 \pm 0.71$ & $921.0 \pm 1.41$ \\
\hline Moisture (g) & $\begin{array}{c}94.10 \pm 0.14 \\
(6.08 \pm 0.14)\end{array}$ & $\begin{array}{l}90.10 \pm 0.07 \\
(7.56 \pm 0.15)\end{array}$ & $\begin{array}{c}93.56 \pm 0.08 \\
(8.21 \pm 0.32)\end{array}$ \\
\hline Protein $(\mathrm{g})$ & $\begin{array}{c}3.60^{c} \pm 0.08 \\
(3.83)\end{array}$ & $\begin{array}{c}13.04^{\mathrm{b}} \pm 0.18 \\
(14.10)\end{array}$ & $\begin{array}{c}13.91^{\mathrm{a}} \pm 0.09 \\
(15.15)\end{array}$ \\
\hline Ether extractives (g) & $\begin{array}{l}3.11^{\mathrm{a}} \pm 0.02 \\
(3.31)\end{array}$ & $\begin{array}{l}2.46^{\mathrm{b}} \pm 0.16 \\
\quad(2.66)\end{array}$ & $\begin{array}{l}2.13^{b} \pm 0.19 \\
(2.32)\end{array}$ \\
\hline Insoluble fiber (g) & $\begin{array}{l}48.86^{\mathrm{b}} \pm 0.11 \\
\quad(52.02)\end{array}$ & $\begin{array}{c}53.83^{a} \pm 0.23 \\
(58.23)\end{array}$ & $\begin{array}{c}41.53^{\mathrm{c}} \pm 0.05 \\
(45.24)\end{array}$ \\
\hline Soluble fiber $(\mathrm{g})$ & $\begin{array}{c}6.46^{\mathrm{a}} \pm 0.57 \\
(6.87)\end{array}$ & $\begin{array}{l}3.26^{\mathrm{b}} \pm 0.11 \\
\quad(3.52)\end{array}$ & $\begin{array}{l}0.43^{\mathrm{c}} \pm 0.20 \\
\quad(0.46)\end{array}$ \\
\hline Ash (g) & $\begin{array}{l}9.14^{\mathrm{a}} \pm 0.01 \\
(9.29)\end{array}$ & $\begin{array}{l}6.14^{\mathrm{c}} \pm 0.05 \\
(6.64)\end{array}$ & $\begin{array}{c}7.63^{b} \pm 0.09 \\
(8.31)\end{array}$ \\
\hline Iron (mg) & $\begin{array}{c}17.06^{\mathrm{a}} \pm 0.23 \\
(17.35)\end{array}$ & $\begin{array}{l}4.74^{c} \pm 0.54 \\
(5.12)\end{array}$ & $\begin{array}{l}6.17^{b} \pm 0.05 \\
\quad(6.72)\end{array}$ \\
\hline Calcium (mg) & $\begin{array}{l}692^{\mathrm{a}} \pm 5.02 \\
\quad(704)\end{array}$ & $\begin{array}{l}416^{\mathrm{b}} \pm 5.98 \\
(450)\end{array}$ & $\begin{array}{l}281^{c} \pm 19.19 \\
\quad(307)\end{array}$ \\
\hline Phosphorus (mg) & $\begin{array}{l}230^{\mathrm{a}} \pm 4.61 \\
(247)\end{array}$ & $\begin{array}{l}233^{\mathrm{a}} \pm 3.71 \\
(252)\end{array}$ & $\begin{array}{l}180^{\mathrm{b}} \pm 4.57 \\
(196)\end{array}$ \\
\hline Ascorbic acid (mg) & $\begin{array}{l}39.16 \pm 0.76 \\
(41.69)\end{array}$ & $\begin{array}{l}35.00 \pm 0.00 \\
(37.86)\end{array}$ & $\begin{array}{l}47.33 \pm 2.51 \\
(51.56)\end{array}$ \\
\hline Total carotenes $(\mu \mathrm{g})$ & $\begin{array}{l}5,410 \pm 10.64 \\
\quad(5,760)\end{array}$ & $\begin{array}{c}32,967 \pm 5.77 \\
(35,663)\end{array}$ & $\begin{array}{c}1,571 \pm 5.12 \\
(1,712)\end{array}$ \\
\hline$\beta$-carotene $(\mu \mathrm{g})$ & $\begin{array}{l}327 \pm 5.91 \\
(348)\end{array}$ & $\mathrm{ND}^{* *}$ & $\begin{array}{l}331 \pm 3.96 \\
(361)\end{array}$ \\
\hline Tannins (mg) & $\begin{array}{l}545.5 \pm 10.64 \\
(580.81)\end{array}$ & $\begin{array}{c}778.20 \pm 14.13 \\
(841.84)\end{array}$ & $\begin{array}{c}778.66 \pm 5.51 \\
(848.30)\end{array}$ \\
\hline Total oxalates (mg) & $\begin{array}{l}0.078^{\mathrm{b}} \pm 0.00 \\
\quad(0.083)\end{array}$ & $\begin{array}{l}0.111^{\mathrm{b}} \pm 0.00 \\
\quad(0.120)\end{array}$ & $\begin{array}{l}0.29^{\mathrm{a}} \pm 0.03 \\
(0.315)\end{array}$ \\
\hline Water soluble oxalates (mg) & $\begin{array}{c}0.019^{c} \pm 0.00 \\
(0.020)\end{array}$ & $\begin{array}{c}0.166^{\mathrm{b}} \pm 0.00 \\
(0.179)\end{array}$ & $\begin{array}{c}0.166^{\mathrm{a}} \pm 0.00 \\
(0.180)\end{array}$ \\
\hline Phytate (mg) & $\begin{array}{c}232.44^{\mathrm{b}} \pm 0.88 \\
(247.48)\end{array}$ & $\begin{array}{c}256.96^{\mathrm{a}} \pm 2.65 \\
(277.97)\end{array}$ & $\begin{array}{c}206.45^{c} \pm 0.56 \\
(224.91)\end{array}$ \\
\hline
\end{tabular}

Note: Data in parenthesis indicate values on dry weight basis (per $100 \mathrm{~g}$ dry weight).

**Not detected. Values represent means of triplicate determinations. Means followed by similar superscripts within a row are not different (Tukey's text, $p<0.05$ ).

ash gourd peel $\left(3.31 \mathrm{~g} .100 \mathrm{~g}^{-1}\right)$ than the other two vegetable peels. All the three vegetable peels were rich sources of insoluble fiber ranging between 45 and 58 g.100 $\mathrm{g}^{-1}$; however, the soluble fiber was low, ranging between 0.46 and $6.87 \mathrm{~g} .100 \mathrm{~g}^{-1}$, respectively. Ash gourd peels were high in ash (9.29 g.100 $100^{-1}$ g), iron, phosphorus, and calcium content (17.35, 234, and $704 \mathrm{mg} .100 \mathrm{~g}^{-1}$, respectively). The ridge gourd peels were the highest in total carotene $\left(35,663 \mu \mathrm{g} .100 \mathrm{~g}^{-1}\right)$; however, $\beta$-carotene was not detected. Ascorbic acid content ranged from 35 to $47 \mathrm{mg} .100 \mathrm{~g}^{-1}$ and tannin content 
from 580 to $848 \mathrm{mg} .100 \mathrm{~g}^{-1}$. The phytate content ranged from 224.91 to $277.97 \mathrm{mg} .100 \mathrm{~g}^{-1}$. Total and water-soluble oxalate content of all analyzed peel samples was very low, indicating that consumption of these peels these may not interfere with mineral absorption.

\section{Extract Yield, Total Polyphenols, and Total Flavonoids}

Yields obtained from water and methanol were higher than in ethanol for all the samples analyzed (Table 2). The yields were the highest in cho-chow marrow in both methanol and aqueous extracts. Ash gourd peel yield was the lowest in the three solvent extracts.

On a dry weight basis, ash gourd peel in methanol extract had the lowest polyphenol (202 mg.100 $\mathrm{g}^{-1}$ ), and ridge gourd peel in aqueous extract had the highest ( $529.34 \mathrm{mg} .100 \mathrm{~g}^{-1}$; see Table 2 ). In the case of cho-chow marrow peel, polyphenol content was high in ethanol followed by methanol and aqueous extracts (228, 358, and $387 \mathrm{mg}$ TAE.100 $\mathrm{g}^{-1}$ sample, respectively). The flavonoid content in the peels ranged from 0.04 to $1.89 \mathrm{mg}$ QE. $100 \mathrm{~g}^{-1}$

TABLE 2 Extract Yield, Polyphenols, Flavonoids, and Total Antioxidant Activity of Dehydrated Vegetable Peels in Solvent Extracts

\begin{tabular}{|c|c|c|c|}
\hline \multirow[b]{2}{*}{ Samples } & \multicolumn{3}{|c|}{ Extracts } \\
\hline & Methanol & Ethanol & Aqueous \\
\hline \multicolumn{4}{|c|}{ Extract Yield (mg.100 $\mathrm{g}^{-1}$ sample) } \\
\hline Ash gourd & $9.36 \pm 0.03$ & $8.24 \pm 0.43$ & $7.04 \pm 0.22$ \\
\hline Cho-chow marrow & $19.32 \pm 0.12$ & $9.03 \pm 0.00$ & $24.97 \pm 0.21$ \\
\hline Ridge gourd & $15.90 \pm 0.42$ & $10.99 \pm 0.09$ & $19.03 \pm 0.01$ \\
\hline \multicolumn{4}{|c|}{ Polyphenols (mg TAE.100 $\mathrm{g}^{-1}$ fresh sample) } \\
\hline Ash gourd & $\begin{array}{c}190 \pm 0.70 \\
(202.29)\end{array}$ & $\begin{array}{l}200 \pm 0.49 \\
(212.94)\end{array}$ & $\begin{array}{l}315 \pm 5.47 \\
(335.39)\end{array}$ \\
\hline Cho-chow marrow & $\begin{array}{l}329 \pm 9.00 \\
(358.78)\end{array}$ & $\begin{array}{l}209 \pm 14.45 \\
(228.05)\end{array}$ & $\begin{array}{l}356 \pm 15.59 \\
(387.84)\end{array}$ \\
\hline Ridge gourd & $\begin{array}{l}436 \pm 10.73 \\
(471.65)\end{array}$ & $\begin{array}{l}304 \pm 9.46 \\
(328.86)\end{array}$ & $\begin{array}{l}489 \pm 5.46 \\
(529.34)\end{array}$ \\
\hline \multicolumn{4}{|c|}{ Flavonoids (mg QE.100 $\mathrm{g}^{-1}$ of fresh sample) } \\
\hline Ash gourd & $\begin{array}{c}0.55 \pm 0.01 \\
(0.58)\end{array}$ & $\begin{array}{l}0.25 \pm 0.01 \\
\quad(0.26)\end{array}$ & $\begin{array}{l}0.18 \pm 0.00 \\
\quad(0.19)\end{array}$ \\
\hline Cho-chow marrow & $\begin{array}{c}1.13 \pm 0.01 \\
(1.23)\end{array}$ & $\begin{array}{l}0.33 \pm 0.01 \\
(0.35)\end{array}$ & $\begin{array}{l}0.16 \pm 0.01 \\
(0.17)\end{array}$ \\
\hline Ridge gourd & $\begin{array}{c}1.75 \pm 0.04 \\
(1.89)\end{array}$ & $\begin{array}{l}0.78 \pm 0.01 \\
\quad(0.84)\end{array}$ & $\begin{array}{l}0.04 \pm 0.00 \\
\quad(0.04)\end{array}$ \\
\hline \multicolumn{4}{|c|}{ Total antioxidant activity ( $\mu$ moles of ascorbic acid.100 $\mathrm{g}^{-1}$ of sample) } \\
\hline Ash gourd & $54,998 \pm 889.50$ & $3,7679 \pm 220.75$ & $13,2215 \pm 333.93$ \\
\hline Cho-chow marrow & $93,444 \pm 455.42$ & $10,2777 \pm 268.69$ & $12,2385 \pm 182.85$ \\
\hline Ridge gourd & $63,464 \pm 331.79$ & $80,196 \pm 175.90$ & $10,1567 \pm 314.96$ \\
\hline
\end{tabular}

Note: Values are means of triplicate determinations. Figures in parenthesis are based on dry weight basis. 
of dry sample. Flavonoid content was the lowest in ridge gourd peel in aqueous extracts and was highest in methanol extract (see Table 2).

The total antioxidant activity was higher in aqueous extracts than in solvent extracts (see Table 2). The value ranged from 37,679 to 132,215 $\mu$ moles of ascorbic acid.100 $\mathrm{g}^{-1}$ of fresh sample. Correlation coefficient showed that the activity was well correlated with ascorbic acid $(\mathrm{R}>0.5)$, tannins $(\mathrm{R}>$ $0.9)$, polyphenols $(\mathrm{R}>0.7)$, and flavonoids $(\mathrm{R}>0.6)$. A strong correlation was observed in methanol extracts with ascorbic acid $(\mathrm{R}>0.8)$ and tannins $(\mathrm{R}>0.6)$ and in aqueous extracts with $\beta$-carotene (i.e., $\mathrm{R}>0.9$; Table 3).

The vegetable peels were analyzed for their free radical scavenging activities (Figure 1A). The three peels showed highest activity in aqueous extracts compared to solvent extracts. Cho-chow marrow peel showed highest activity (87.32\%) followed by ridge gourd (85.4\%) and ash gourd (63.31\%) peels. The peels in ethanol extracts showed the lowest antioxidant activity. The radical-scavenging activity of $\mathrm{DPPH}$ expressed as $\mathrm{IC}_{50}$ (concentration of the extract required to inhibit $50 \%$ of the initial $\mathrm{DPPH}$ free radical) in methanol, ethanol, and aqueous extracts were: 21, 52, and $8 \mathrm{mg}$ for ash gourd; 11, 45, and $6 \mathrm{mg}$ for the cho-chow marrow peels; and 7, 24, and $5 \mathrm{mg}$ for the ridge gourd peel, respectively. While the total carotene was positively correlated with free radical scavenging activity $(\mathrm{R}>0.6), \beta$-carotene and ascorbic acid did not show any correlation (see Table 3$)$. Tannins $(\mathrm{R}>0.6)$, polyphenols $(\mathrm{R}>0.8)$, and flavonoids $(\mathrm{R}>0.9)$ were also strongly correlated with free radical scavenging activity,

Cho-chow marrow peel had the highest reducing power compared to the other two peels in all the three extracts (see Figure 1B). The reducing power of samples was in the order of cho-chow marrow $>$ ridge gourd $>$ ash

TABLE 3 Association between Antioxidant Components and Antioxidant Activity of Dehydrated Vegetable Peels as Determined by Different Assays

\begin{tabular}{|c|c|c|c|c|c|c|}
\hline Extracts & $\begin{array}{c}\text { Total } \\
\text { carotene }\end{array}$ & $\beta$-carotene & $\begin{array}{c}\text { Ascorbic } \\
\text { acid }\end{array}$ & Tannins & Polyphenols & Flavonoids \\
\hline \multicolumn{7}{|c|}{ Total antioxidant activity } \\
\hline Methanol & -0.41 & 0.35 & 0.88 & 0.68 & 0.29 & 0.21 \\
\hline Ethanol & 0.06 & -0.12 & 0.55 & 0.94 & 0.71 & 0.63 \\
\hline Aqueous & -0.91 & 0.93 & 0.46 & -0.73 & -0.95 & -0.98 \\
\hline \multicolumn{7}{|c|}{ Free radical scavenging activity } \\
\hline Methanol & 0.84 & -0.87 & -0.33 & 0.82 & 0.98 & 0.99 \\
\hline Ethanol & 0.97 & -0.98 & -0.63 & 0.58 & 0.88 & 0.92 \\
\hline Aqueous & 0.63 & -0.68 & -0.03 & 0.95 & 0.98 & 0.96 \\
\hline \multicolumn{7}{|c|}{ Reducing power } \\
\hline Methanol & 0.01 & -0.07 & 0.59 & 0.93 & 0.67 & 0.60 \\
\hline Ethanol & -0.33 & 0.28 & 0.84 & 0.74 & 0.37 & 0.28 \\
\hline Aqueous & -0.22 & 0.16 & 0.77 & 0.81 & 0.47 & 0.38 \\
\hline
\end{tabular}

Correlation coefficient, $\mathrm{R}$ values; values in block letters indicate high positive correlation. 

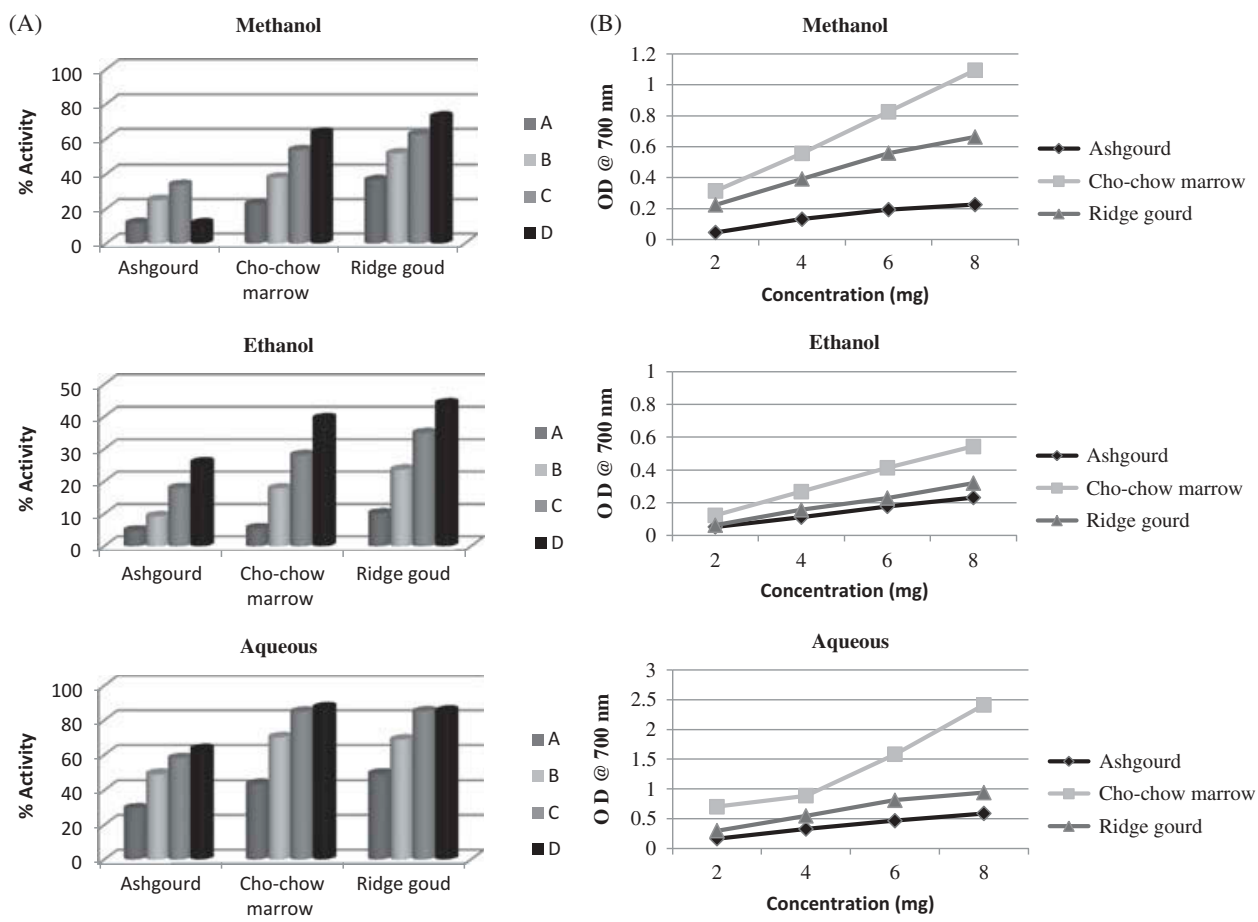

FIGURE 1 (A) Free radical scavenging activity of dehydrated vegetable peels by DPPH method. Values represent means of triplicate determinations. (B) Reducing power of dehydrated vegetable peels in different extracts.

gourd. Reducing power assay was positively correlated with ascorbic acid, tannins, polyphenols, and flavonoids (see Table 3). A strong correlation was observed with tannins $(\mathrm{R}>0.7)$ and ascorbic acid $(\mathrm{R}>0.6)$.

\section{Bile Acid Binding of Samples}

The vegetable peels showed high extent of bile acid binding (Figure 2). Ridge gourd peel had the highest bile binding (98.95\%) followed by ash gourd (91.07\%) and cho-chow marrow peel, (61.78\%). A negative correlation was observed with total dietary fiber of vegetable peels; however, soluble and insoluble dietary fiber $\mathrm{R}$ values were 0.74 and 0.94 , respectively, indicating strong positive correlation (see Table 3). Thus, bile acid binding was correlated to the insoluble and soluble dietary fiber content.

In vitro Inhibition of $\alpha$-Amylase

Methanol and aqueous extracts were tested for the $\alpha$-amylase inhibition assay to detect activity, which might be extrapolated to detect a 
(A)

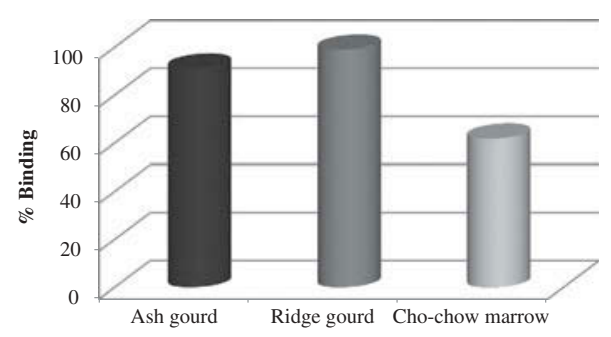

(B)

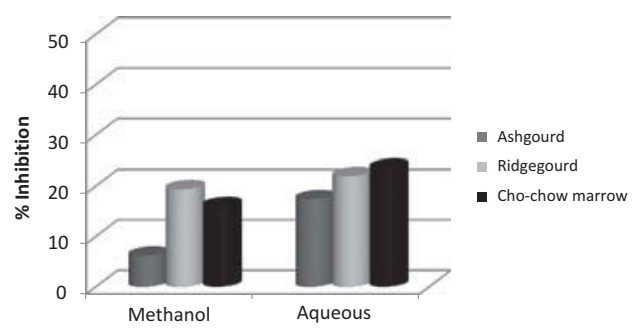

FIGURE 2 (A) Extent of bile acid binding by vegetable peels. (B) Alpha-amylase inhibitory activity of vegetable peels. Values represent means of triplicate determinations.

potential anti-diabetic effect using this in vitro method. Acarbose, the positive control demonstrated an $\mathrm{IC}_{50}$ value of $45 \mu \mathrm{g} \cdot \mathrm{mL}^{-1}$ (Figure 2B). Acarbose used as standard in 20, 40, 60, 80, and $100 \mu \mathrm{g} \cdot \mathrm{mL}^{-1}$ concentration exhibited inhibition of $\alpha$-amylase in aqueous media to the extent of 15.0\%, 36.33\%, 50.50\%, 76.5\%, and 99.86\%, respectively. The percentage inhibition showed that cho-chow marrow peel in aqueous extract demonstrated strong inhibition activities compared to the methanol extracts. The methanol extract of the ridge gourd peel also demonstrated inhibitory activities.

\section{DISCUSSION}

The results confirmed that vegetable peels were a good source of nutrient content, especially ridge gourd peel, which was an excellent source of dietary fiber and $\beta$-carotene. Extraction yield and antioxidant activity of extracts were strongly dependent on the solvent, due to the fact that the antioxidant potential of compounds vary with solvent polarity (13). The results showed that extracts with the more polar solvents (methanol and aqueous extract) showed higher antioxidant activity. Vegetable materials contain many polyphenols with antioxidant activity that could be potentially safe natural antioxidants for the food industry (15). Ismail, Marjan, and Foong (11) reported the phenolic content of spinach, swamp cabbage, kale, shallots, and

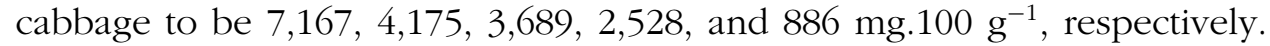
Flavonoids are plant pigments that are synthesized from phenylalanine and generally display marvelous colors in the flowering parts of plants (8). The results of this study on cho-chow marrow peel showing highest activity (87.32\%) in aqueous extracts is in accordance with earlier reports (17).

Dietary fiber protects against cardiovascular diseases, diverticulosis, constipation, irritable colon, colon cancer, and diabetes (24). The insoluble 
fraction of the fiber has been related to the intestinal regulation and the soluble fiber to the decrease of cholesterol levels and adsorption of intestinal glucose (12). However, the reports on this have been controversial $(7,9,12)$. In this study, the correlation values showed that the bile acid binding was strongly associated with insoluble as well as soluble fiber content of samples.

A therapeutic approach to decreasing hyperglycemia is to retard absorption of glucose by inhibiting carbohydrate hydrolyzing enzymes, such as $\alpha$-amylase and $\alpha$-glucosidase. The potential of anti-diabetic activity of the vegetable peels was carried out focusing on the inhibitory effects on $\alpha$ amylase. The methanol and aqueous extracts had considerable inhibitory activity, suggesting that these samples contained both lipophilic and lipophobic components that may contribute to the inhibitory activity in reducing the sugar level.

\section{FUNDING}

The source of funding for this study, the Council of Scientific and Industrial Research-New Delhi, India, is gratefully acknowledged. The authors have no conflict of interest associated with this research.

\section{REFERENCES}

1. Association of Official Analytical Chemists. 1970. Estimation of tannins. In Official Methods of Analysis, $11^{\text {th }}$ ed. Washington, DC: Author.

2. Association of Official Analytical Chemists. 2005. Determination of moisture. In Official Methods of Analysis, $18^{\text {th }}$ ed. Washington, DC, Author.

3. Arvouet-Grand, A., B. Vennat, A. Pourrat, and P. Legret. 1994. Standardisation d'un extrait de propolis et identification des principaux constituants. Journal. de Pharmacie. de Belgique. 49:462-468.

4. Asp, N. G., C. G. Johansson, H. Hallmer, and M. Siljestrom. 1983. Rapid enzymatic assay of insoluble and soluble dietary fiber. J. Agric. Food. Chem. 31(3): 476-482.

5. Baker, C. J. L. 1952. The determination of oxalates in fresh plant material. Analyst 77:340-344.

6. Bernfeld, P. 1955. Amylases $\alpha$ and $\beta$. In S. P. Colowick and N. O. Koplan, eds. Methods in Enzymology, vol. I. Academic Press, New York. pp 149-153.

7. Chau, C., S. Wu, and M. Lee. 2007. Physicochemical changes upon micronization process positively improve the intestinal health-enhancement ability of carrot insoluble fiber. Food. Chem. 104:1569-1574.

8. Clifford, A. H. and S. L. Cuppett. 2000. Review: Anthocyanins-nature, occurrence and dietary burden. J. Sci. Food Agric. 80:1063-1072. 
9. Hsu, P. K., P. J. Chien, C. H. Chen, and C. F. Cahu. 2006. Carrot insoluble fiberrich fraction lowers lipid and cholesterol absorption in hamsters. LWT Food Sci. Technol. 39:337-342.

10. Huang, C. M., and N. H. Dural. 1995. Adsorption of bile acids on cereal type food fibers. J. Food Process. Eng. 18:243-266.

11. Ismail, A., Z. M. Marjan, and C. W. Foong. 2004. Total antioxidant activity and phenolic content in selected vegetables. Food. Chem. 87:581-586.

12. Lunn J., and J. L. Buttriss. 2007. Carbohydrates and dietary fiber. British Nutrition Foundation. Nutr. Bull. 32:21-64.

13. Marinova, E. M., and N. Yanishlieva. 1997. Antioxidative activity of extracts from selected species of the family Lamiaceae in sunflower oil. Food. Chem. 58:245-248.

14. Matthaus, B. 2002. Antioxidant activity of extracts obtained from residues of different oilseeds. J. Agric. Food Chem. 50:3444-3452.

15. Moure, A., J. M. Cruz, D. Franco, J. M. Dominguez, J. Sineiro, H. Dominguez, M. J. Nunez, and J. C. Parajo. 2001. Natural antioxidants from residual sources. Food Chem. 72:145-171.

16. Oktay, M., I. Culcin, and O. I. Kufrevioglu. 2003. Determination of in vitro antioxidant activity of fennel (Foeniculum vulgare) seed extracts. Lebensm. Wiss. Technol. 36:263-271.

17. Ordonez, A. A. L., J. D. Gomez, M. A. Vattuone, and M. I. Isla. 2006. Antioxidant activities of Sechium edule (Jacq.) Swartz extracts. Food Chem 97:452-458.

18. Oreopoulou, V., and C. Tzia. 2007. Utilization of Plant By-Products for the Recovery of Proteins, Dietary Fibers, Antioxidants, and Colorants in Utilization of By-Products and Treatment of Waste in the Food Industry, eds. V. Oreopoulou and W. Russ. Springer, New York. pp 209-232.

19. Oser, B. L. 1965. Hawks Physiological Chemistry, $14^{\text {th }}$ ed. Tata McGraw Hill Publishing Co. Ltd., New Delhi, India. pp. 1263-1265.

20. Oyaizu, M. 1986. Studies on product of browning reaction prepared from glucose amine. Japan J. Nutr. 44:307-315.

21. Prieto, P., M. Pineda, and M. Aguilar. 1999. Spectrophotometric quantitation of antioxidant capacity through the formation of a phosphomolybdenum complex: Specific application to the determination of vitamin E. Anal. Biochem. 269:337-341.

22. Raghuramulu, N., M. K. Nair, and S. Kalyansundaram. 2003. A Manual of Laboratory Techniques. National Institute of Nutrition, ICMR, Jamai-Osmania, Hyderabad, India.

23. Ranganna, S. 1986. Handbook of Analysis and Quality Control for Fruit and Vegetable Products, $2^{\text {nd }}$ ed. Tata McGraw-Hill, New Delhi, India.

24. Rodriguez, R., A. Jimenez, J. Fernandez-Bolanos, R. Guillen, and A. Heredia. 2006. Dietary fibre from vegetable products as source of functional ingredients. Trends Food Sci. Technol. 17:3-15.

25. Taussky, H. H., and E. Shorr. 1953. A micro colorimetry method for determination of inorganic phosphorus. J. Biol. Chem. 202:675-685.

26. Thompson, D. B., and J. W. Erdman, Jr. 1982. Phytic acid determination in soybeans. J. Food. Sci. 47:513-517. 